\title{
Physico-chemical and Sensory Properties of Frankfurter-type Fish Sausage
}

\author{
Nkrumah $\mathbf{T}^{*}$, Akwetey W. $\mathbf{Y}^{*}$ \\ Department of Animal Science, Faculty of Agriculture, Kwame Nkrumah University of Science and Technology (KNUST), \\ Kumasi, Ghana \\ *Corresponding author: theresahnkrumah12@gmail.com, wyakwetey.canr@knust.edu.gh
}

\begin{abstract}
In this study pH, water holding capacity and cooking yield of meats (Mackerel, Catfish and Pork) and their corresponding sausages were determined. Acidity $(\mathrm{pH})$ and water holding capacity were also determined. Sensory evaluation was conducted using a Hedonic scale rating in order to evaluate consumer acceptability of the sausages. Sausage appearance, taste, texture, juiciness, flavour, mouthfeel, and overall acceptability were evaluated on a scale of 1 (Dislike Extremely) to 9 (Like Extremely). Pork and catfish sausages recorded significantly $(\mathrm{p}<0.05)$ higher water holding capacity than mackerel sausage in both raw and cooked forms. Also $\mathrm{pH}$ of mackerel and catfish were higher $(\mathrm{P}<0.05)$ than pork in both raw and cooked states. Most of the sensory panelists prefer pork sausage to fish sausages. It was concluded that though catfish frankfurter-type sausage had high cooking yield but majority of consumers prefer pork sausage.
\end{abstract}

Keywords: fish sausage, acidity, water holding capacity, pork sausage, sausage appearance

Cite This Article: Nkrumah T, and Akwetey W. Y., "Physico-chemical and Sensory Properties of Frankfurter-Type Fish Sausage.” American Journal of Food Science and Technology, vol. 6, no. 3 (2018): 118-122. doi: 10.12691/ajfst-6-3-6.

\section{Introduction}

Among the food resources of the world, fish and fishery products are very important as sources of food especially in some countries that are deficient in livestock production [1]. Fish is known to be one of the cheapest sources of animal protein and other vital nutrients required in human diets [2]. However, Olatunde et al. [1] observed that the quality of harvest is markedly affected by the ease of deterioration and spoilage in fresh fish. After stunning fish, certain changes begin to take place; muscle gradually changes due to chemical, physicochemical, and biological activities. The processes that take place include the activity of the actomysin enzyme during rigor mortis, autolytic degradation, microbial growth and oxidation of fat [3]. All processes run simultaneously during storage. Okoro et al. [4] also indicated that there are numerous problems confronting the wide field of fisheries and some of which seem to be related to the keeping quality of fish. Onset of rigor mortis owing to loss of the limp elastic texture of the muscle which contracts before becoming hard and stiff are some of the factors. This condition more often than not lasts for a day or more in iced fish, after which rigor resolves. Fish deterioration can be detected and assessed with sensory analysis (appearance, texture, flavour, odour and taste), physicochemical and microbial analysis. The flavour of fish changes during the deteriorating process as a result of autolytic degradation.
Bacteria that grow in fish are mostly favoured by $\mathrm{pH}$ range of 6 and 8 while less growth occurs at extremes of $\mathrm{pH}[5]$.

Moreover, the characteristic sweet, meaty flavour of fish flesh is due to a compound called inosinic acid [6]. The breakdown of inosinic acid during autolysis results in the loss of this sweet meaty flavour. Hypoxanthine, which is produced from the breakdown of inosinic acid, also contributes to the bitter flavour of spoilt fish. Autolysis also aids indirectly to fish flavors by supplying compounds which bacteria convert to other substances having unpleasant flavor and odour. The colour of muscle may also change during the deteriorating process. This study therefore sought to produce two types of fish frankfurter and to determine their physico-chemical and sensory properties affecting eating quality.

\section{Materials and Methods}

\subsection{Experimental Location and Design}

The experiment was carried out at the Meat Science and Processing Unit, Department of Animal Science, KNUST. Four treatments: T1 = Pork frankfurter without corn starch; (+VE PFS) served as the positive control; T2 = Mackerel frankfurter (MFS); T3 = Catfish frankfurter (CFS) and T4 $=$ Pork frankfurter with corn starch (-VE PFS), negative control. 
Table 1. Ingredients used in sausage formulation

\begin{tabular}{lcccc}
\hline \multicolumn{2}{c}{ Frankfurter types } \\
\hline Ingredient (\%) & T1=PFS (+VE) & T2 = MFS & T3=CFS & T4=PFS (-VE) \\
\hline Minced mackerel & 0.00 & 70.40 & 0.00 & 0.00 \\
Minced catfish & 0.00 & 0.00 & 70.40 & 0.00 \\
Minced pork & 67.40 & 0.00 & 0.00 & 65.40 \\
Minced pork fat & 5.00 & 0.00 & 0.00 & 5.00 \\
Curing salt* & 1.2 & 1.2 & 1.2 & 1.2 \\
Phosphate & 0.7 & 0.7 & 0.7 & 0.7 \\
Corn starch & 0.00 & 2.00 & 2.00 & 2.00 \\
Mixed spices*** & 0.70 & 0.70 & 0.70 & 0.70 \\
Ice flakes & 25.00 & 25.00 & 25.00 & 25.00 \\
Total & 100.00 & 100.00 & 100.00 & 100.00 \\
\hline
\end{tabular}

PFS $(+$ VE $)=$ Pork Frankfurter without corn starch, MFS= Mackerel Frankfurter, CFS= Catfish Frankfurter, and PFS $(-$ VE $)=$ Pork Frankfurter with corn starch. ${ }^{*}$ Curing salt was added in the form of sodium nitrite (4g of nitrite to $10 \mathrm{Kg}$ common salt), $* *$ Phosphate was added in the form of disodium phosphate $\left(\mathrm{Na}_{2} \mathrm{HPO}_{4}\right)$, ${ }^{* * *}$ Mixed spice $=$ chilli pepper $(0.3 \%)$, black pepper $(0.125 \%)$, garlic $(0.125 \%)$ and nutmeg $(0.15 \%)$.

Pork frankfurter was produced to enable consumers differentiate between the sausage types. The experimental design was Complete Randomized Design (CRD) with four treatments and three replicates in a $2 \times 4$ factorial arrangement for the determination of sensory and physiochemical components.

\subsection{Fish Sausage Formulation}

Each mixture was finely chopped and filled using a manually operated stuffer into $26 \mathrm{~mm}$ diameter hog casings, and tied off in desired sausage lengths. The sausages were hot smoked for $45 \mathrm{~m}$ and scalded in $70^{\circ} \mathrm{C}$ water for $30 \mathrm{~m}$. A meat thermometer was used to monitor the core temperature of the sausages in order to prevent over cooking. The scalded sausages were allowed to cool under running tap water, packaged and labeled for storage in a freezer for quality analysis and for further studies.

\subsection{Parameters Measured}

\subsubsection{Physico-chemical Characteristics}

Acidity $(\mathrm{pH})$ was determined at the Meat Science and Processing Unit using the procedure described by Bates and Vijh [7], water holding capacity was determined as described by [8].

\subsubsection{Sensory Properties}

The sausages were evaluated at week one and six during frozen storage. Untrained consumer panelists $(n=45)$ evaluated the frankfurters based on how they liked product appearance, juiciness, texture, flavour and after taste characteristics. All participants were regular consumers of frankfurters and other processed meats. The panelists evaluated the frankfurters using a 9-point Hedonic scale $(9=$ like extremely, $5=$ neither like nor dislike and 1 = dislike extremely). The products were sliced to approximately equal lengths of $2 \mathrm{~cm}$, coded with 3 -digit random numbers and oven warmed at $180^{\circ} \mathrm{C}$ for 2 minutes before serving. In order to control individual differences between panelists, the order of serving samples was randomized and counter balanced so that all treatments occurred equally. Biscuit was offered alongside test samples for the consumer panelists to eat between testing samples in order to neutralize the sensory profile of each test sausages. The taste evaluation took place under conditions [9] that ensured independence throughout the entire duration. The room was well illuminated with white fluorescent lights and there was no noise or awful odour that could possibly distract the attention of panelists.

\subsection{Statistical Analysis}

Data obtained for $\mathrm{pH}$ and water holding capacity were subjected to one-way analysis of variance (ANOVA) while the sensory parameters were subjected to $2 \times 4$ factorial analysis. $\mathrm{pH}$ and water holding capacity were analysed using Genstat statistical package version 12 and sensory parameters by GLM Procedure [10]. Significant differences between means were separated at 5\% using Least significant difference test.

\section{Results and Discussions}

\subsection{Acidity (pH) and Water Holding Capacity (WHC)}

Low $\mathrm{pH}$ and accelerated $\mathrm{pH}$ decline are related to the development of low water-holding capacity and consequently high purge due to denaturation of many proteins [11] especially those concerned with muscle functionality.

Treatment $\mathrm{T} 1$ and $\mathrm{T} 4$ recorded higher $\mathrm{pH}(\mathrm{p}<0.05)$ in both raw and cooked sausages while the observed $\mathrm{pH}$ in T2 and T3 were similar in both raw and cooked frankfurters (Table 2). The high $\mathrm{pH}$ observed in T1 and T4 could be due to prolonged stress prior to slaughtering the pigs, and consequently resulting in higher ultimate $\mathrm{pH}$. Barbut [12] reported that stress, accelerated post-mortem metabolism and other biochemical changes can affect pork muscle quality postmortem. The result of which is high $\mathrm{pH}$ and increased water holding capacity. Van de Perre et al. [13] determined the influence of stunning on $\mathrm{pH}$ of pork and observed that some risk factors like the noise level produced during unloading, the rate of panting and the use of an electric prod can affect the $\mathrm{pH}$ and temperature of a meat. According to Serenius et al. [14] lowering the temperature of carcass decreases metabolic processes and reduces the rate of $\mathrm{pH}$ decline. Meats with $\mathrm{pH}$ below 5.4 have the tendency of increasing firmness in 
processed products [15]. Thus T1 and T4 were expected to be relatively less firm compared to T2 and T3 because of their relatively low pH [16]. Lawrie and Ledward [11] stated that high $\mathrm{pH}$ improves juiciness of products. The high acidity observed in T2 and T3 could favor decreased microbial attack [16] because reduced $\mathrm{pH}$ media create unfavourable conditions for microbial activities and thereby prolonging the shelf-life of such product.

Treatment one (T1) recorded the highest WHC while T2 had the least in both emulsion and sausage (Table 2). The observed differences in WHC for both emulsion and cooked products were significantly $(\mathrm{p}<0.05)$ different. T2 which recorded the highest acidity was observed to hold less water in both emulsion and sausage. This supports the report that a lower $\mathrm{pH}$ results in reduced WHC of final products [17]. T3 confirms this report in the both sausage and in the emulsion. Water holding capacity measured as drip loss has high importance in meat production because of its' financial implications. In general it can be said that meat with a low WHC has an unattractive appearance $[11,18]$. The findings of this study support Lawrie and Ledward [11] because T2 scored low for appearance during sensory evaluation (Table 4). Also, a high WHC in emulsion and sausage could be attributed to much more stable meat protein matrix formed which led to smaller release of water and fat, thus improving binding properties [19].

According to Hamm [20], there are many factors that influence the water holding capacity of muscle tissue. These are internal or external factors. Species, age, size, muscle type, amount of intra muscular fat and muscle tissue condition post mortem forms the internal factors. External factors include feeding patterns, season and location of catching and handling post slaughter. According to Shenouda, [21], reduced WHC in fish frankfurter (catfish and mackerel) can be primarily due to denaturation/aggregation of actin and myosin (thin filament and thick filament respectively) that are responsible for toughness and tenderness depending on once bridge between them. Actin and myosin which are the main contractile proteins are responsible for functional properties [21]. The WHC is affected by the changes that take place in muscle tissue post mortem. Changes in chemical composition during processing, like salting could also have influenced WHC [19].

In general, $\mathrm{pH}$ is commonly known to be one of the most important factors to affect the WHC of a product [20,22].

Table 2. Acidity (pH), Water Holding Capacity and Cooking Yield

\begin{tabular}{cccccc}
\hline Parameter & \multicolumn{4}{c}{ Frankfurter- type } & SEM \\
& T1 & T2 & T3 & T4 & \\
\hline pH (Emulsion) & $5.60^{\mathrm{a}}$ & $5.35^{\mathrm{b}}$ & $5.38^{\mathrm{b}}$ & $5.58^{\mathrm{a}}$ & 0.01666 \\
pH (Sausage) & $5.78^{\mathrm{a}}$ & $5.41^{\mathrm{c}}$ & $5.44^{\mathrm{c}}$ & $5.63^{\mathrm{b}}$ & 0.00726 \\
WHC (Emulsion \%) & $24.60^{\mathrm{a}}$ & $7.90^{\mathrm{c}}$ & $22.41^{\mathrm{a}}$ & $19.07^{\mathrm{b}}$ & 1.01959 \\
WHC (Sausage \%) & $16.89^{\mathrm{a}}$ & $4.32^{\mathrm{c}}$ & $16.66^{\mathrm{a}}$ & $13.78^{\mathrm{b}}$ & 1.00024 \\
Cooking Yield (\%) & $68.04^{\mathrm{d}}$ & $79.07^{\mathrm{b}}$ & $83.03^{\mathrm{b}}$ & $91.55^{\mathrm{a}}$ & 1.44705 \\
\hline
\end{tabular}

$\mathrm{T} 1=$ pork frankfurter without corn starch, $\mathrm{T} 2=$ mackerel frankfurter, $\mathrm{T} 3$ = catfish frankfurter and T4 = pork frankfurter with corn starch.

\subsection{Cooking Yield}

Treatment four (T4) recorded the highest $(\mathrm{p}<0.05)$ cooking yield while $\mathrm{T} 1$ recorded the least. The high cooking yield (91.55\%) observed in T4 could be as a result of the corn starch added, which increased its moisture retention capacity [19]. Corn starch contains carbohydrates that contributed to water absorption during emulsification. Thus, T4 absorbed and retained much moisture during cooking compared to $\mathrm{T} 1$ which did not contain corn starch. Brown and Zayas [23] made similar observations when corn flour was used as meat extenders. There were no differences ( $p>0.05)$ between T2 and T3 in terms of cooking yield; and both T2 and T3 yielded higher $(p<0.05)$ than the positive control (T1). The observed differences could be due to the meat type used. According to Peng et al. [24] processing yield could be affected by type of meat used. This could be attributed to higher protein content of fish than pork which probably improved functionality of the products thereby decreasing cooked losses [25]. Thus lower cooking yield in T1 can be attributed to the absence of corn starch (extender).

FAO [26] reported that the flesh of mackerel contains about $60-74 \%$ water. This could be one of the reasons accounting for poor WHC of mackerel affecting the cooking yield of mackerel sausage.

\subsection{Cost of Production}

A simple analysis of the ingredients used in product formulations (Table 3.) revealed that the costs (Gh\$) per kg were respectively 9.85, 7.72, 8.94 and 7.12 for $\mathrm{T} 1, \mathrm{~T} 2$, $\mathrm{T} 3$ and $\mathrm{T} 4$.

Table 3. Cost of ingredients used in sausage production

\begin{tabular}{lcccc}
\hline Ingredient (GH4) & \multicolumn{4}{c}{ Frankfurter- type } \\
\hline & T1 & T2 & T3 & T4 \\
Pork fat & 1.8 & 0 & 0 & 1.8 \\
Minced meat & 28.39 & 24.20 & 32.07 & 27.55 \\
Corn starch & 0 & 1.32 & 1.32 & 1.32 \\
Total cost & 30.19 & 25.52 & 33.39 & 30.67 \\
Cost of Production $(\mathrm{Gh}) / \mathrm{kg}$ & 9.85 & 7.72 & 8.94 & 7.12 \\
\hline
\end{tabular}

NB: Cost of production is less spice, phosphate, curing salt, casings, labour, machinery and water

$\mathrm{T} 1=$ pork frankfurter without corn starch, $\mathrm{T} 2=$ mackerel frankfurter, $\mathrm{T} 3=$ catfish frankfurter and T4 = pork frankfurter with corn starch

\subsection{Sensory Parameters}

Table 4 shows the sensory parameters determined during the study. T1 and T4 recorded significantly higher $(p<0.05)$ values in all the sensory parameters tested, and T3 was also higher $(\mathrm{p}<0.05)$ than $\mathrm{T} 2$ for all sensory attributes. It could be deduced that most of the panelists generally preferred pork sausages to fish sausages. According to [17], every meat product has its typical smell and taste and also different animal species have different tastes. [17] further stated that $\mathrm{pH}$ is important for the taste and flavour of meats, while Lawrie and Ledward [11] also indicated that high $\mathrm{pH}$ improves juiciness of meat products. Relating the $\mathrm{pH}$ (Table 2) to the juiciness, flavour and taste of sausages (Table 4) in this research, it was observed that the result supports Lawrie and Ledward [11]. $\mathrm{T} 1$ and $\mathrm{T} 4$ recorded higher $\mathrm{pH}$ values indicating juicier products, which reflected in the sensory scores for juiciness of these sausages, compared to T2 and T3 which had lower $\mathrm{pH}$ values. Moreover, appearance, juiciness, 
texture, taste and overall acceptability of T4 (negative control $=$ pork with corn starch) was not significantly different $(\mathrm{p}<0.05)$ from $\mathrm{T} 1$ (positive control $=$ pork sausages without corn starch). Brown and Zayas [23] have observed similar findings with the use of meat extenders in general.

Table 4. Sensory attributes of pork and fish frankfurters during storage

\begin{tabular}{|c|c|c|c|c|c|c|c|}
\hline Source & Appearance & Flavour & Juiciness & Taste & Mouth feel & Texture & Overall acceptability \\
\hline \multicolumn{8}{|c|}{ Frankfurter- type } \\
\hline $\mathrm{T} 1$ & $7.71^{\mathrm{a}}$ & $7.45^{\mathrm{a}}$ & $7.30^{\mathrm{a}}$ & $7.58^{\mathrm{a}}$ & $7.37^{\mathrm{a}}$ & $7.28^{\mathrm{a}}$ & $7.59^{\mathrm{a}}$ \\
\hline $\mathrm{T} 2$ & $5.26^{c}$ & $5.42^{\mathrm{C}}$ & $4.99^{c}$ & $4.89^{c}$ & $4.86^{\mathrm{c}}$ & $5.22^{\mathrm{C}}$ & $4.93^{c}$ \\
\hline T3 & $7.02^{\mathrm{b}}$ & $6.36^{\mathrm{b}}$ & $6.52^{\mathrm{b}}$ & $6.34^{\mathrm{b}}$ & $6.25^{\mathrm{b}}$ & $6.43^{\mathrm{b}}$ & $6.58^{\mathrm{b}}$ \\
\hline $\mathrm{T} 4$ & $7.74^{\mathrm{a}}$ & $7.31^{\mathrm{a}}$ & $7.29^{\mathrm{a}}$ & $7.30^{\mathrm{a}}$ & $7.09^{\mathrm{a}}$ & $6.94^{\mathrm{a}}$ & $7.54^{\mathrm{a}}$ \\
\hline SEM & 0.15 & 0.16 & 0.16 & 0.18 & 0.17 & 0.17 & 0.17 \\
\hline F.pr. & $<.0001$ & $<.0001$ & $<.0001$ & $<.0001$ & $<.0001$ & $<.0001$ & $<.0001$ \\
\hline \multicolumn{8}{|l|}{ Storage } \\
\hline Week 1 & $6.93 a$ & $6.84^{\mathrm{a}}$ & $6.67^{\mathrm{a}}$ & $6.77^{\mathrm{a}}$ & $6.60^{\mathrm{a}}$ & $6.61^{\mathrm{a}}$ & $6.89^{\mathrm{a}}$ \\
\hline Week 6 & $6.93^{\mathrm{a}}$ & $6.43^{\mathrm{b}}$ & $6.39^{\mathrm{b}}$ & $6.29^{\mathrm{b}}$ & $6.19^{\mathrm{b}}$ & $6.33^{\mathrm{a}}$ & $6.4^{\mathrm{b}}$ \\
\hline SEM & 0.11 & 0.12 & 0.12 & 0.13 & 0.17 & 0.12 & 0.12 \\
\hline F.pr. & 0.9919 & 0.0124 & 0.0833 & 0.0079 & 0.0180 & 0.1138 & 0.0064 \\
\hline Interaction & 7.76 & 7.60 & 7.38 & 7.69 & 7.38 & 7.40 & 7.71 \\
\hline T1 x Week 1 & 7.66 & 7.30 & 7.23 & 7.48 & 7.36 & 7.16 & 7.48 \\
\hline T1 x Week 6 & 5.07 & 5.73 & 5.24 & 5.31 & 5.24 & 5.33 & 5.33 \\
\hline T2 x Week 1 & 5.45 & 5.11 & 4.73 & 4.48 & 4.49 & 5.12 & 4.53 \\
\hline T2 x Week 6 & 7.18 & 6.67 & 6.62 & 6.73 & 6.67 & 6.60 & 6.91 \\
\hline T3 x Week 1 & 6.86 & 6.05 & 6.41 & 5.95 & 5.84 & 6.25 & 6.25 \\
\hline T3 x Week 6 & 7.73 & 7.36 & 7.42 & 7.36 & 7.11 & 7.09 & 7.60 \\
\hline T4 x Week 1 & 7.75 & 7.27 & 7.16 & 7.25 & 7.07 & 6.80 & 7.48 \\
\hline \multicolumn{8}{|l|}{ T4 x Week 6} \\
\hline SEM & 0.21 & 0.23 & 0.23 & 0.26 & 0.24 & 0.24 & 0.23 \\
\hline F.pr. & 0.4046 & 0.5791 & 0.8694 & 0.3534 & 0.1801 & 0.9934 & 0.4059 \\
\hline
\end{tabular}

Superscript abcwithin columns are significantly different $(<0.05)$, Scale $1=$ dislike extremely, $2=$ dislike very much, $3=$ dislike moderately, $4=$ like slightly, $5=$ neither like nor dislike, $6=$ like slightly, $7=$ like moderately, $8=$ like very much and $9=$ like extremely.

$\mathrm{TxN}=$ interaction between treatment and storage duration, $\mathrm{T} 1=$ pork frankfurter without corn starch, T2= mackerel frankfurter, T3 = catfish frankfurter and T4 = pork frankfurter with corn starch.

The sausages kept frozen for six weeks had lesser values in all attributes compared to week one of storage. This results support a report by Barroso et al., [27], that during frozen storage meat muscle can denature and aggregate especially the myofibrillar proteins. Such changes result in altered functional properties, changed textural attributes and reduced water holding capacity and juiciness. Resulting in hard, dry and fibrous products with reduced eating quality. Even though there seemed to be lesser values in week six than week one, the observed differences were not statistically different. Thus all the sausage samples can be stored frozen for six weeks without any effects on sensory characteristics.

\section{Conclusion}

Pork frankfurter with corn starch holds higher water than without corn starch, mackerel frankfurter and catfish frankfurter. There was no difference in cooking yield between catfish frankfurter and pork frankfurter (with corn starch). Consumers prefer pork frankfurters to fish frankfurters.

However, catfish frankfurter has higher cooking yield and WHC compared to mackerel frankfurters.

\section{Recommendation}

It is recommended that, further work could be done to improve on flavour, taste, mouthfeel, appearance, juiciness and texture of fish frankfurters. Pork could be partially replaced with fish in frankfurters in order to improve functional and binding properties.

\section{References}

[1] Olatunde, K. A., Bamgbose, O., Arowolo, T. A., George, F. O. A. and Bada, B. S. Effect of Processing and Storage on the Trace Metal Concentration and Freshness Quality of Catfish (Clarias gariepinus). Food Science and Quality Management, 9: 1-7. 2012.

[2] Anihouvi, V. B., Kindossi, J.M. and Hounhouigan, J. D. (2012). Processing and Quality Characteristics of Some Major Fermented Fish Products from Africa: A Critical Review Department of Nutrition and Food Science - University of Abomey- Calavi, 01BP 526 Cotonou, BENIN. 2012 , Pp 292.

[3] Huss, H. H. Quality and Quality Changes in Fresh Fish.FAO Fisheries Technical paper, 1995, Pp 348.

[4] Okoro, C. C, Aboaba, O. O. and Babajide, O. J. Quality Assessment of a Nigerian Marine Fish, Mullet (Liza Falcipinnis) Under Different Storage Conditions. New York Science Journal, 3(8): 21-28.2010.

[5] Pierard, D., Crowcroft, N., De Bock, S., Potters, D., Crabbe, G., Van Loock, F. and Lauwers, S. A Case-Control Study of Sporadic Infection with $\mathrm{O} 157$ and Non-O157 Verocytotoxin-Producing Escherichia coli. Epidemiology and Infection, 122(03): 359365.1999

[6] Erickson, M. C. Lipid oxidation: Flavour and Nutritional Quality Deterioration in frozen foods. In Quality in frozen food. Springer US.1997, Pp:141-173.

[7] Bates, R. G. and Vijh, A. K. Determination of pH; theory and practice. Journal of the Electrochemical Society,120(8):263c263c.1973.

[8] Suzuki, A., Kojiman, N., Ikeuchi, Y., Moriyama, N., Ishizuka, T. and Tokushige $\mathrm{H}$. Carcass Composition and Meat Quality of Chinese Purebred and European x chinesse cross breeds pig. Meat Science 29: 31-41.1991. 
[9] Mackie, D. A., Butler, G. and Larmond, E. Laboratory Methods for Sensory Analysis of Food. Canada Communication Group, Pub. Centre. 1991, Pp. 1-87.

[10] SAS Institute. SAS/STAT9.3 userÕs guide: the GLIMMIX procedure.SAS Institute, Cary, NC. 2012.

[11] Lawrie, R. A. and Ledward, D.A. Meat Science, Seventh edition, Cambridge: Woodhead publishing series in Food Science and Technology, 2006. Pp 337.

[12] Barbut, S. Colour Measurements for Evaluating the Pale Soft Exudative (PSE) occurrence in Turkey meat. Food Resource International. 26: 39-43. 1993.

[13] Van de Perre, V., Permentier, L., De Bie, S., Verbeke, G. and Geers, R. Effect of Unloading, Lairage, Pig Handling, Stunning and Season on pH of Pork. Meat Science, 86(4), 931-937. 2010.

[14] Serenius, T., Stalder, K. J., Baas, T. J., Mabry, J. W., Goodwin, R. N., Johnson, R. K. and Miller, R. K.. National Pork Producers Council Maternal Line National Genetic Evaluation Program: A comparison of sow longevity and trait associations with sow longevity. Journal of Animal Science, 84(9): 2590-2595.2006.

[15] Lonergan, H. E. and Lonergan, S. M. Mechanisms of WaterHolding Capacity of Meat: The role of postmortem biochemical and structural changes. Meat science, 71(1): 194-204, 2005.

[16] Leistner, L. and Roedel, W. Water Activity; Influence on Food Quality. (Rockland, L.B. and Stewart. G.F., eds), Academic Press, London, England. 1995, Pp 855-916.

[17] Food and Agriculture Organization (FAO). Protein and Amino Acid Requirements In Human Nutrition. Report of a joint WHO/FAO/UNU expert consultation. Geneva, Switzerland. (WHO technical report series; No. 935). 2007.
[18] Santos, C., Roserio, L. C., Goncalves, H. and Melo, R.S. Incidence of different pork quality categories in a Portuguese slaughterhouse: A survey. Meat Science, 38:279-287.1994.

[19] Fennema, O. R. Comparative Water Holding Properties of Various Muscle Foods. Journal of Muscle Food, 1(4): 363-381.1990.

[20] Hamm, R. The Effect of Water on the Quality of Meat and Meat Products: Problems and Research Needs. In Properties of water in foods. Springer Netherlands. 1985, Pp. 591-602.

[21] Shenouda, S. Y. K. Theories of Protein Denaturation. During Frozen Storage of Fish Flesh. Advance Food Research, 26: 275275.1980.

[22] Nott, K. P., Evans. S. D and Hall, L. D. Quantitative magnetic resonance imaging of fresh and frozen-Thawed Trout. Magnetic Resonance Imagine, 17(3): 445-455.1999.

[23] Brown, L. M., and Zayas, J. F. Corn Germ Protein Flour as an Extender in Broiled Beef Patties. Journal of Food Science, 55(4), 888-892.1990.

[24] Peng, W., Xu, X. L. and Zhou, G. H. Effects of Meat and Phosphate Level on Water-Holding Capacity and Texture of Emulsion-Type Sausage During Storage. Agricultural Sciences in China, 8(12): 1475-1481. 2009.

[25] Fakagawu, N. K. Protein Requirements: Methodological Controvesy amid a call for change. American Journal of Clinical Nutrition, 99(4): 761-762, 2014.

[26] Food and Agriculture Organization (FAO). Sharing Innovative Experience; Example of Success in Agriculture and Rural Development in the South. 5: 2001, Pp. 240-254.

[27] Barroso, M., Careche, M. and Borderias, A. J. Quality Control of Frozen Fish Using Rheological Techniques. Trends in Food Science and Technology, 9(6): 223-229.1998. 